IZA DP No. 6869

Human Capital Externalities and Employment Differences across Metropolitan Areas of the U.S.

John V. Winters

September 2012 


\title{
Human Capital Externalities and Employment Differences across Metropolitan Areas of the U.S.
}

\author{
John V. Winters \\ University of Cincinnati \\ and IZA
}

Discussion Paper No. 6869

September 2012

\author{
IZA \\ P.O. Box 7240 \\ 53072 Bonn \\ Germany \\ Phone: +49-228-3894-0 \\ Fax: +49-228-3894-180 \\ E-mail: iza@iza.org
}

\begin{abstract}
Any opinions expressed here are those of the author(s) and not those of IZA. Research published in this series may include views on policy, but the institute itself takes no institutional policy positions. The IZA research network is committed to the IZA Guiding Principles of Research Integrity.

The Institute for the Study of Labor (IZA) in Bonn is a local and virtual international research center and a place of communication between science, politics and business. IZA is an independent nonprofit organization supported by Deutsche Post Foundation. The center is associated with the University of Bonn and offers a stimulating research environment through its international network, workshops and conferences, data service, project support, research visits and doctoral program. IZA engages in (i) original and internationally competitive research in all fields of labor economics, (ii) development of policy concepts, and (iii) dissemination of research results and concepts to the interested public.
\end{abstract}

IZA Discussion Papers often represent preliminary work and are circulated to encourage discussion. Citation of such a paper should account for its provisional character. A revised version may be available directly from the author. 


\section{ABSTRACT}

\section{Human Capital Externalities and Employment Differences across Metropolitan Areas of the U.S.}

It has been well documented that employment outcomes often differ considerably across areas. This paper examines the extent to which the local human capital level, measured as the share of prime age adults with a college degree, has positive external effects on labor force participation and employment for U.S. metropolitan area residents. The empirical results suggest that the local human capital level has positive externalities on the probability of labor force participation and employment for both women and men. We also find that less educated workers generally receive the largest external benefits.

JEL Classification: J21, J24, R23

Keywords: employment, labor force participation, human capital externalities, agglomeration

Corresponding author:

John V. Winters

Department of Economics

University of Cincinnati

P.O. Box 210371

Cincinnati, OH 45221

USA

E-mail: john.winters@uc.edu

\footnotetext{
* The author thanks Henry Overman, David Brasington, Janice Compton, Barry Hirsch, Curtis Simon, Henry Thompson, Nick Williams, seminar participants at Auburn University, Auburn University Montgomery, and the University of Cincinnati, participants at the 2010 North Regional Science Council Meetings in Denver and the 2010 Southern Economic Association Meetings in Atlanta, and three anonymous referees for helpful comments and suggestions. Any errors or omissions, however, are solely attributable to the author.
} 


\section{Introduction}

Employment outcomes differ quite considerably across countries and regions. Even within a developed country like the United States, there are still large differences in wages, labor force participation, and employment across local labor markets. These geographic differences in labor outcomes have powered a large literature seeking to explain their determinants. One such determinant is the aggregate stock of human capital. The stock of human capital in a local labor market is likely to be an important source of geographic differences in labor outcomes because of both direct and external effects. The direct effects are obvious. Workers with greater human capital are more productive, earn higher wages, and are more likely to be employed (Psacharopoulos and Patrinos 2004). Many researchers, however, have suggested that the local level of human capital might have positive external effects on its residents. ${ }^{1}$ That is, high human capital workers are thought to improve labor market outcomes for other workers in the area.

Much of the literature on human capital externalities has focused on differences in wages and wage growth. A number of such studies have shown that wages in an area are positively correlated with average education levels, even after controlling for individual worker characteristics (e.g., Rauch 1993; Moretti 2004a; Glaeser and Saiz 2004). ${ }^{2}$ These human capital externalities on wages are thought to occur for several reasons. First, there may be pecuniary externalities due to imperfect substitution between high skilled and low skilled workers in the production process (Katz and Murphy 1992; Moretti 2004a; Ciccone and Peri 2006). Holding all

\footnotetext{
${ }^{1}$ See Moretti (2004b) Lange and Topel (2006), and Henderson (2007) for reviews of the literature on human capital externalities.

${ }^{2}$ There is some question, however, whether the observed positive effects of local human capital on wages are causal. Workers likely sort into labor markets based on employment opportunities, and the highly skilled are likely to be the most mobile and seek out areas with high quality business environments (Chen and Rosenthal 2008; Combes, Duranton and Gobillon 2008; Wozniak 2010). Areas with otherwise strong labor markets are likely to attract educated workers and see their average education levels rise. Some studies such as Moretti (2004a) and Dalmazzo and Blasio $(2007 \mathrm{a}, \mathrm{b})$ use instrumental variables to try to isolate the effects of exogenous increases in average education levels, but Lange and Topel (2006) question whether commonly used instruments are valid.
} 
else constant, an increase in the quantity of high skilled workers will increase the marginal productivity of low skilled workers but decrease the marginal productivity of high skilled workers because of imperfect substitution. Manning (2004), Kaplanis (2010), and Mazzolari and Ragusa (2011) suggest that human capital externalities may also result from increased consumer demand by high skilled workers with high incomes. Some of the higher consumption demand by high skilled workers is for locally produced goods and services that are not easily tradable across areas such as healthcare, education, entertainment, restaurant meals, and housekeeping. Greater demand for locally produced goods and services will increase wages for local workers that provide them.

A third source of human capital externalities on wages comes from what Moretti (2004a) calls human capital spillovers. Human capital spillovers occur when being near highly skilled workers increases the skills of other workers. ${ }^{3}$ In other words, an individual's productivity is increased by interacting with and learning from high skilled workers (Jovanovic and Rob 1989; Glaeser 1999; Glaeser and Maré 2001). ${ }^{4}$ Spillovers, therefore, have positive effects on productivity for all workers, though the magnitudes may differ across types of workers. For example, by having less knowledge and skills, low skill workers may have more opportunities to learn from high skill workers and receive larger spillovers. Alternatively, if high skill workers are better at learning from other workers, they may learn more even if they have fewer opportunities to learn. Moretti (2004a) finds that human capital externalities on wages are

\footnotetext{
${ }^{3}$ Skill accumulation results in both higher wages and faster wage growth (Glaeser and Maré 2001; Wheeler 2006).

${ }^{4}$ Alternatively, Berliant, Reed, and Wang (2006) develop a model with horizontal knowledge exchange in which workers differ in the types of knowledge that they possess and search for partners with whom to exchange ideas to improve production efficacy.
} 
positive for workers of all skill levels, but largest for the least skilled workers. This is consistent with multiple explanations for human capital externalities. ${ }^{5}$

Several studies also suggest a number of other important external effects of education. Lochner and Moretti (2004) find that education decreases criminal activity and Milligan, Moretti and Oreopoulos (2004) find that education increases civic participation. More generally, Shapiro (2006) and Winters (2011a) suggest that an educated populace increases the overall quality of life in an area. Doms, Lewis, and Robb (2010) argue that more educated areas have higher rates of entrepreneurship and more positive business outcomes. Researchers have also suggested that the positive external effects of human capital cause initially highly educated areas to experience faster population and employment growth as individuals flock to be near the highly educated (Glaeser, Scheinkman and Shleifer 1995; Simon 1998, 2004; Black and Henderson 1999; Simon and Nardinelli 2002). Furthermore, Berry and Glaeser (2005) and Winters (2011b) suggest that it is mostly educated individuals who are moving to high human capital areas. ${ }^{6}$

Largely overlooked, however, have been the external effects of human capital on labor force participation and employment. Manning (2004) and Kaplanis (2010) are important exceptions looking at external effects on employment, but both assume that positive effects on employment are due to increased demand for non-tradable goods and services and do not consider human capital externalities on labor supply. ${ }^{7}$ A few other studies have examined the

\footnotetext{
${ }^{5}$ A fourth source of human capital externalities discussed by Acemoglu (1996) results from a pecuniary externality due to costly bilateral search between firms and workers. According to Acemoglu (1996) skilled workers increase the productivity of physical capital, and an increase in the skill level of workers causes firms to invest more in physical capital. The higher level of physical capital then makes both high skill and low skill workers more productive, resulting in higher wages for all workers. Wheeler (2001) develops a similar model in which physical capital and worker skill are complementary and urban agglomeration yields more efficient matches and a higher return to skill acquisition.

${ }^{6}$ Florida (2002) also suggests that the concentration of Bohemians in an area plays an important role in attracting high human capital individuals. Similarly, Florida, Mellander and Stolarick (2008) argue in favor of the underlying importance of a "creative class" of artists and workers employed in creative occupations.

${ }^{7}$ Glaeser (2010) also looks at human capital externalities on unemployment.
} 
effects of human capital measures on aggregate employment outcomes (e.g., Simon 1998;

Partridge and Rickman 1995; Nistor 2009), but such results typically include direct effects as well as external effects. In much of the previous literature and in this paper, the local level of human capital is measured as the share of the adult population with at least a four-year college degree, sometimes referred to as the college share. There are surely elements of human capital besides formal education (Bacolod, Blum and Strange 2009, 2010), but education is certainly an important component of human capital.

The current paper suggests that human capital externalities increase employment probabilities for local residents largely by influencing individual labor supply decisions. More specifically, this paper seeks to address whether being in a highly educated labor market makes individuals more likely to participate in the labor market and find employment, controlling for the individual's own education and other characteristics. We estimate the magnitude of human capital externalities on participation and employment using a pooled cross-section of individuals residing in 283 U.S. metropolitan areas in 1980 and $2000 .{ }^{8}$ We also separately explore using the location of land grant institutions of higher education as an instrumental variable for the local human capital level and control for time-invariant city characteristics using city fixed effects. For our preferred specifications, we find that the local human capital level has positive externalities on the probability of labor force participation and employment for both women and men. We also find that less educated workers generally receive the largest external benefits.

\footnotetext{
${ }^{8} \mathrm{Fu}$ (2007) and Rosenthal and Strange (2008) suggest that human capital wage externalities are highly localized and attenuate with distance. This could also be true with participation and employment externalities and future work should take this into account.
} 


\section{Conceptual Framework}

The external effects of local human capital on productivity are likely to affect the probability of labor force participation and employment. We illustrate these effects with a simple labor supply model where workers gain skills through work experience, workers accumulate skills more quickly by interacting with high human capital workers, and skill accumulation increases both present and future wages. Each individual must choose whether to supply his labor to the market. $L_{i}$ is a binary variable equal to one if individual $i$ chooses to participate in the labor force and 0 otherwise. For simplicity, this modeling abstracts from the fact that individuals can choose how much labor to supply, i.e., how many hours to work. Individual $i$ 's labor supply decision will depend on the market wage that he is offered in the current period, $W_{i}$, the net present value of higher future wages from the skills that he acquires from working in the present ${ }^{9}, N P V_{i}$, and the individual's opportunity cost of working, $O C W_{i}$, i.e., the monetary value of the utility that he would get from not working in the market. Individuals who do not work in the market receive utility from producing and consuming non-market goods such as leisure and family life. The individual's labor supply decision can be represented as follows:

$L_{i}= \begin{cases}0 & \text { if } W_{i}+N P V_{i} \leq O C W_{i} \\ 1 & \text { if } W_{i}+N P V_{i}>O C W_{i}\end{cases}$

That is, the individual will supply his labor if the benefits from doing so, $W_{i}+N P V_{i}$, exceed the costs, $O C W_{i}$.

Human capital externalities are likely to increase labor force participation both through higher current wages and through greater skill accumulation that increases the NPV of future wages. Higher current wages could result from a number of external factors related to human

\footnotetext{
${ }^{9}$ We assume for simplicity that all workers have the same discount rate for future payments.
} 
capital including imperfect substitution between skilled and unskilled labor, increased consumer demand for locally produced goods by high human capital workers, and human capital spillovers. Human capital spillovers exist if workers gain more skills from working alongside high human capital workers than from working with low human capital workers. Human capital spillovers are likely to increase labor supply even beyond the effects on current wages. The opportunity to learn new skills from working alongside high human capital workers provides an additional benefit to participating in the labor force because the skills gained also result in higher future wages, which show up in the $N P V$ term in the labor supply decision. Furthermore, individuals are unlikely to learn new skills simply from living in the same geographic area as high human capital individuals; spillovers require two parties to somehow interact and spillovers of employment-related skills are mostly likely to occur through participation and interaction in the labor market.

Investigating the external effects of human capital on labor force participation and employment presents opportunities for new insights into the nature of human capital externalities. In particular, our main estimates control for the current wage in the local market, so that finding human capital externalities on labor force participation provides strong evidence of human capital spillovers in particular because controlling for the current wage accounts for competing explanations based on imperfect substitution and increased demand for local goods. Again human capital spillovers increase not only the current wage but also the NPV of future wages. Even controlling for the current wage, human capital spillovers will increase labor force participation because individuals receive future benefits from the skills acquired while working alongside highly skilled workers. 


\section{Empirical Framework and Data}

This paper examines the external effects of the local human capital level on labor force participation $(L)$ and employment $(E)$ using a linear probability model. ${ }^{10}$ The conceptual framework suggests that human capital externalities increase labor force participation and increased participation is expected to increase the probability that an individual will be employed. We model the separate probability of each outcome for individual $i$ of gender $g$ in city $c$ in year $t$ as a linear function of a vector of individual characteristics $(X)$, the share of adults in the city with a college degree $(S)$, and a vector of other city characteristics $(Z):{ }^{11}$

$L_{i g c t}=X_{i g c t} \beta_{L g t}+S_{c t} \gamma_{L g}+Z_{c t} \varphi_{L g}+\mu_{\text {Ligct }}$,

$E_{i g c t}=X_{i g c t} \beta_{E g t}+S_{c t} \gamma_{E g}+Z_{c t} \varphi_{E g}+\mu_{E i g c t}$.

The individual characteristics consist of a number of variables commonly found to affect individual participation and employment outcomes and include dummy variables for highest level of education completed, five year age group, marital status, the presence and number of own children in the household, nonwage income ${ }^{12}$, whether an individual is Black, Hispanic, Asian, or Other, citizenship status, and whether the individual lives in his or her state of birth. ${ }^{13}$

The parameters for the individual characteristics $(\beta)$ are allowed to vary by year and gender. Summary statistics for the individual characteristics are reported in Appendix Table A.

\footnotetext{
${ }^{10}$ While there are some advantages to using non-linear models such as probit and logit, many applied econometricians use linear probability models (LPM) because of the practical advantages. In particular, there are a number of computational and theoretical issues with using a probit model with fixed effects, such as the city fixed effects used in some regressions in this study. There are also issues with estimating logit models with instrumental variables. The linear model allows both instrumental variables and area fixed effects and facilitates easier interpretation of marginal effects. In results not shown, we also estimate the cross-section and fixed effects regressions using a logit model and find results similar to those for the linear regressions.

${ }^{11}$ Metropolitan areas are the geographic unit of analysis in this study and correspond to quasi-independent regional labor markets. We use the terms city and metropolitan area interchangeably.

${ }^{12}$ Nonwage income is computed as family income minus the wage income of the individual and therefore includes the wage income of other family members.

${ }^{13}$ Whether an individual lives in his or her state of birth is intended as a proxy for proximity to family. Compton and Pollak (2011) suggest that proximity to family has a substantial effect on female labor force participation due to greater access to childcare.
} 
We first estimate the external effects of human capital by Ordinary Least Squares (OLS) using pooled cross-sectional variation in the city characteristics. However, if there are unobserved city characteristics that are correlated with both the college share and the employment outcomes, the cross-sectional estimates of the $\gamma$ s may be biased and inconsistent. We attempt to obtain consistent estimates using two separate methods, instrumental variables and city fixed effects.

Following Moretti (2004a) and Iranzo and Peri (2009), we use the presence of a landgrant higher education institution in the metropolitan area as an instrument for the cross-sectional variation in the share of adults in the metro area with a college degree or higher using two-stage least squares (2SLS) regression. The presence of a land-grant institution will be a valid instrument if it is correlated with the local human capital level and uncorrelated with the error term. We can test for the first part of the requirement, but not for the second if we have only one instrument. Land-grant institutions are often thought to be a good instrument for the local human capital level because they were established in the late $19^{\text {th }}$ century and therefore are not affected by recent events. However, it still could be the case that land-grant institutions improve local labor market opportunities beyond the effect that they have on creating an educated population. For example, land grant institutions directly employ faculty and staff and are often the largest single employer in relatively small areas. Land grant institutions may also bring external dollars into the local area through research grants or parental transfers to students attending college. Such an inflow of dollars from outside the area might strengthen the local demand for labor and 
improve employment outcomes for local residents. Thus, the presence of a land-grant institution may be a questionable instrument. ${ }^{14}$

Our second approach is to estimate models that control for any time-invariant city characteristics by adding a set of city fixed effects $(\alpha):^{15}$

$L_{i g c t}=X_{i g c t} \beta_{L g t}+S_{c t} \gamma_{L g}+Z_{c t} \varphi_{L g}+\alpha_{L g c}+\mu_{L i g c t}$,

$E_{i g c t}=X_{i g c t} \beta_{E g t}+S_{c t} \gamma_{E g}+Z_{c t} \varphi_{E g}+\alpha_{E g c}+\mu_{E i g c t}$.

Some cities may have above average labor market outcomes and a highly educated population because of time-invariant characteristics such as the presence of a state or federal capital. The fixed effects models control for such time-invariant characteristics. As a third approach, one might like to estimate fixed effects models that also instrument for the human capital level. However, this approach is not adopted in the current study. The presence of a land-grant institution does not change over time and does not predict changes in the human capital level over time, so it cannot be used as an instrument in fixed effects models. Other instruments have been used to explain variations in the human capital level over time such as the lagged age structure of the population (Moretti 2004a; Dalmazzo and Blasio 2007a,b) and the push-driven immigration of highly educated workers (Iranzo and Peri 2009), but we are not confident in their appropriateness as instruments. The age structure of the population, for example, has been suggested to have its own effect on wage and employment outcomes by at least a few studies (e.g., Elhorst 1995; Shimer 2001). ${ }^{16}$ Similarly, immigrants are a small part of the skilled labor

\footnotetext{
${ }^{14}$ Abel and Deitz (2011) emphasize that the effects of colleges and universities in building the stock of collegeeducated labor in an area result not only from supply effects but also from the increased demand for skilled labor that higher education institutions facilitate.

${ }^{15}$ The city fixed effects models are estimated by including a set of city dummy variables in OLS regressions. With two years of data, controlling for city fixed effects is similar to measuring city level variables as differences over time and then regressing the time-difference of the dependent variable against the time differences of the explanatory variables.

${ }^{16}$ In results not shown, we experiment with using the age structure of the population as an instrument for the change in the local human capital level over time. We find statistically significant estimates of positive human capital
} 
force in most local labor markets and it is unclear if the external effects of skilled immigrants are the same as the external effects of skilled natives.

The data in this study come primarily from the 1980 and 2000 decennial census $5 \%$ microdata samples available from IPUMS (Ruggles et al. 2008). There are a couple of important limitations with the use of this data. First, the IPUMS data do not allow identification of geographic areas with populations less than 100,000. Consequently, the lowest level of identifiable geography in the IPUMS data, county groups in 1980 and PUMAs in 2000, often include both metropolitan and non-metropolitan areas. We, therefore, assign each county group (PUMA in 2000) to a metropolitan area if more than 50 percent of the population of the county group (PUMA) is contained within the metropolitan area. Using this procedure, results in 283 metropolitan areas that can be identified in both 1980 and 2000. The second limitation, which is closely related to the first, is that metropolitan area definitions change over time, but the data limitations discussed above prevent us from being able to use perfectly consistent geographic definitions for all metropolitan areas. Thus, the inconsistency in geographic definitions could lead to measurement error and add considerable noise to our estimations.

The sample investigated includes all individuals between the ages of 25 and 55 who resided in one of the 283 metropolitan areas that are identified in both 1980 and 2000 . We limit the sample to prime age individuals because the young and old often have weaker attachment to the labor force. Note also that both the labor force participation and employment regressions include all prime age individuals regardless of their labor force participation status. Our main estimates also measure the local human capital level as the share of prime age (i.e. 25-55) adults

externalities but the magnitudes are implausibly large (nearly ten times as large as OLS estimates) and not believable given that the age structure is thought to have its own effect on employment outcomes. 
with at least a four-year college degree. Many of the city-level control variables, however, are not constructed exclusively from the prime age population.

Additional city-level explanatory variables include a number of factors thought to affect labor supply, labor demand, or both. ${ }^{17}$ Many of these additional city control variables are potentially endogenous and the results are estimated both with and without them. As outlined in the conceptual framework, the wage is one important variable. Juhn, Murphy and Topel (1991, 2002) argue that the national decrease in male employment rates since 1967 can be largely explained by falling real wages. In the present study, wages are measured as the regressionadjusted average log wage in the city computed as the city fixed effects, $\pi$, in a gender-specific log wage regression on individual characteristics and city fixed effects:

$\log W_{i g c t}=X_{i g c t} \delta_{g t}+\pi_{g c t}+e_{i g c t}$

Higher wages are expected to increase the supply of labor but reduce the demand for labor (Blackaby and Manning 1992; Partridge and Rickman 1995, 1997). Therefore, the wage is expected to increase participation but the effect on the probability of employment is somewhat ambiguous.

We also include a measure of the cost of housing in the metropolitan area. Housing costs are measured as the regression-adjusted average log rent in the city computed as the city fixed effects, $\phi$, in a regression of $\log$ rents on a vector of housing characteristics, $H$, and city fixed effects:

$\log R_{i c t}=H_{i c t} \rho_{t}+\phi_{c t}+\xi_{i c t}$

Rents are used instead of housing values because the former is a better measure of the present user cost of housing (Winters 2009), but results are not qualitatively affected by using housing

\footnotetext{
${ }^{17}$ Elhorst (2003) reviews the literature on regional employment differentials.
} 
values instead of rents. Higher rents reflect higher land costs, which are expected to reduce the demand for labor. However, higher rents may increase labor force participation, especially for women if households need a second earner to pay for the more expensive housing (Black, Kolesnikova, and Taylor 2008b; Johnson 2009). The effect of rents on the probability of employment is ambiguous.

Geographic differences in wages and rents can also help control for local amenities. People and firms are mobile and seek out areas that give them the highest utility and profits. Spatial equilibrium requires utility differences across areas to be arbitraged away through compensating differentials in housing and labor markets. In other words, areas with nicer local amenities will have higher rents, lower wages, or some combination of the two. The local human capital level itself is thought be an important amenity that increases the quality of life in an area even beyond the effects of human capital spillovers (Shapiro 2006; Winters 2011a). If human capital participation and employment externalities are fully capitalized into wages and rents, then controlling for these could impose too strong of a test and cause our estimates to be overly conservative. However, to the extent that the marginal participants in the labor force are not the marginal migrants determining the distribution of wages and rental prices across cities, human capital participation and employment externalities are unlikely to be fully capitalized into wages and rents. $^{18}$

Because the most skilled workers are often the most mobile, high amenity areas are also likely to disproportionately attract high skilled individuals. Controlling for wages and rents also helps control for unobserved worker characteristics and partially alleviates concerns about

\footnotetext{
${ }^{18}$ For example, consider an infra-marginal household whose location decision is based primarily on the wage offered to the primary earner. Human capital externalities may affect the labor force participation decision of a second person in the household but this is unlikely to be fully capitalized into wages and rents because the household would have resided in the area regardless of the human capital externalities. In this case, human capital participation and employment externalities would increase the utility of infra-marginal households.
} 
workers with unobservable skills sorting into high human capital labor markets. However, we should use caution in interpreting the wage and rent coefficients as causal. In results not shown, we also experiment with higher order terms for log wages and log rents, e.g., quadratic, cubic, and quartic specifications. The results for the college share explanatory variable are not sensitive to these alternate specifications. Recall also that by controlling for the wage in the participation and employment regressions, human capital externalities are only allowed to affect these outcomes through the higher NPV of future wages that results from greater skill accumulation due to human capital spillovers.

The next variable is the mean commute time for persons who commute to work. Black, Kolesnikova, and Taylor (2008a) argue convincingly that longer commute times in a city reduce labor force participation rates, especially for married women. Similarly, we also expect longer commutes will decrease employment. We also include the log of employment density in the city as an explanatory variable. Dense concentrations of economic activity have been consistently shown to increase productivity, and it may also be true that employment density positively affects participation and employment. Furthermore, workers with unobserved skills might sort into dense areas. Thus, we expect that the log of employment density will have a positive effect on participation and employment.

Our next two city-level variables are based on labor demand effects due to the industry mix in the city. The first of the two is the predicted unemployment rate, $P U R_{c t}$, in city $c$ in year $t$ based on the city's current industry mix and the industry-specific national unemployment rate for industry $j$ in year $t, U R_{j t}$, as follows:

$P U R_{c t}=\sum_{j} \eta_{j c t} U R_{j t}$ 
, where $\eta_{j c t}$ measures the share of the labor force in city $c$ and year $t$ that is currently employed in or was most recently employed in industry $j$. The predicted unemployment rate is expected to have a negative effect on both participation and employment (Armstrong and Taylor 2000). Previous literature has also suggested that industrial diversity might improve employment prospects in an area (e.g., Simon 1988; Diamond and Simon 1990; Neumann and Topel 1991; Partridge and Rickman 1995, 1997). Following previous literature we construct a city-specific industry Herfindahl Index, $H I_{c t}$, as a measure of industrial diversity as follows:

$H I_{c t}=\sum_{j} \theta_{j c t}^{2}$

, where $\theta_{j c t}$ is the share of employment in city $c$ and year $t$ that is in industry $j$. In other words, $H I$ is computed as the sum of the squared city- and year-specific industrial shares. Larger values of the Herfindahl Index mean that employment is relatively more concentrated in a few industries. Therefore, $H I$ is expected to have a negative effect on both participation and employment.

A few studies have also suggested that the age structure of the population might affect employment outcomes, though there is disagreement on the expected effects. Elhorst (1995) suggests that a relatively young population will worsen employment outcomes and a relatively older population will improve employment outcomes. Shimer (2001), however, argues that a larger share of young workers actually increases participation and employment. We next include two variables intended to control for the age structure of the population. First, we measure the youth share as the share of the population between the ages of 16 and 24 . Second, we measure the elderly population as the share of the population ages 65 and older.

Previous literature has also suggested that employment outcomes are adversely affected by the generosity of unemployment insurance benefits (e.g., Partridge and Rickman 1995; 
Moomaw 1998). We, therefore, next include a measure of the generosity of unemployment benefits in the local labor market. We measure unemployment generosity for each state by dividing total state expenditures on unemployment insurance, computed from census of government data, by the total number of weeks labor force participants were unemployed during the year, computed from March Current Population Survey (CPS) data. We then assign the unemployment generosity of states to metropolitan areas wholly within the state's boundaries. If a metro area crosses states, its unemployment generosity is computed as a population weighted average of the unemployment generosity of the states it spans. The variable is then converted to $\log$.

Figures 1a-1f present scatter-plots of the relationships between mean participation and employment rates and the college share for the 283 metro areas in 1980, 2000, and the changes between the years. These scatterplots suggest positive relationships in the raw data, but do not control for individual or city level characteristics. Table 1 provides summary statistics for the city-level variables for 1980, 2000, and the changes between the two years. The labor force and employment ratios are the city-level means illustrated in Figures 1a-1f and do not account for differences in individual characteristics across cities. Ratios are reported by gender and education levels. Men have higher mean participation and employment rates than women, but these gender gaps decline over time. The table also shows that participation and employment ratios vary considerably across education groups with participation and employment increasing with education levels. Finally, the table also shows that there is meaningful variation across cities for all of the ratios, but the variation across cities decreases with the education level. In other words, the variation in employment outcomes across cities is largest for the least educated workers suggesting that they might be the most affected by local labor market conditions. 


\section{Empirical Results}

This section discusses the empirical results for the external effects of human capital on the probability of labor force participation and employment using a pooled cross-section of individuals who resided in one of the 283 metro areas in 1980 and 2000. We first present results that treat the local human capital level as exogenous and are estimated via OLS. We then present pooled cross-sectional results in which we instrument for the local human capital level using the presence of a land-grant institution in the metropolitan area. Separate OLS and IV crosssectional results for 1980 and 2000 are qualitatively similar to the results for the pooled crosssection and are available from the author. Finally, we present results that control for any timeinvariant characteristics of cities using city fixed effects, but treat changes in the human capital level between 1980 and 2000 as exogenous. All regressions are estimated separately for women and men.

\subsection{Pooled Cross-Section OLS Results}

Tables 2 and 3 present OLS results for women and men without and with the additional city-level controls discussed above. All results include the individual controls, and the results can be interpreted as external effects of human capital. The results in Tables 2 and 3 suggest that the share of adults with a college degree has a positive external effect on the probability of labor force participation (LFP) for both women and men that is statistically significant at the one percent level. The effects on LFP are larger for women than men, both with and without the additional city-level controls. The LFP coefficients are also slightly larger with the city-level controls for both men and women. The female coefficient of 0.201 with additional controls suggests that a 0.10 increase in the share of adults with college degrees externally increases 
female LFP by 0.0201 , i.e., by about 2.0 women per 100 . For males a 0.10 increase in the share of adults with college degrees externally increases LFP by 0.0129 . These are both economically significant effects. Since the results in Table 3 control for local wages, evidence of human capital externalities on labor force participation suggest that a particular mechanism is at work, human capital spillovers.

Increased participation is also expected to increase the probability of employment. The results in Tables 2 and 3 suggest that the college share externally increases the probability of being employed for both men and women, both with and without the additional city-level controls. The effects are again larger with the additional city controls and larger for women than for men. The results with additional controls suggest that a 0.10 increase in the college share externally increases the share of the population that is employed by 0.0272 for women and by 0.0216 for men. The external effects on employment probabilities are also slightly larger than the effects on labor force participation. Increased labor supply, therefore, plays an important role in increasing employment, but may not be the only mechanism to increase employment outcomes. In results not shown, we also find that human capital externalities significantly decrease the probability of being unemployed. ${ }^{19}$

Table 3 also reports the results for the additional city-level explanatory variables included as controls. $^{20}$ Because some of these are potentially endogenous, results should be interpreted with caution. The log wage in the local area has a positive effect on labor force participation for both women and men with statistically significant coefficients of 0.085 and 0.036 . The log wage coefficient on employment is positive for women and negative for men, but neither coefficient is statistically significant. Log rent has statistically insignificant effects on both female outcomes

\footnotetext{
${ }^{19}$ One can compute the effect on the probability of unemployment as the LFP effect minus the employment effect.

${ }^{20}$ Corresponding coefficient estimates for the individual coefficients are reported in Appendix Table A.
} 
but significantly reduces male participation and employment with coefficients equal to -0.026 and -0.022 . The mean commute time reduces both participation and employment with significant coefficients of -0.005 for women and -0.002 for men. Log employment density has a statistically insignificant effect on female participation and employment, but a significantly positive effect on male participation and employment with coefficients of 0.005 and 0.006 . The predicted unemployment rate has insignificant effects on female participation and employment, but surprisingly positive effects on male participation and employment with coefficients of 1.239 and 1.400, that are significant at the ten percent level. The industry Herfindahl Index is statistically insignificant in all the regressions in Table 3. The percentage of the population age 16-24 significantly worsens outcomes for both men and women. The youth share reduces participation with coefficients of -0.401 for women and -0.347 for men and decreases employment with coefficients of -0.487 and -0.444 . This is in contrast to the results in Shimer (2001) but consistent with results in Elhort (1995). Somewhat surprisingly, the share of the population age 65 and over also significantly worsens outcomes. The senior share reduces female participation and employment with coefficients of -0.179 and -0.209 and reduces male participation and employment with coefficients of -0.265 and $-0.327 .{ }^{21}$ Finally, unemployment insurance generosity significantly reduces participation and employment for both women and men with participation coefficients equal to -0.014 and -0.005 and employment coefficients equal to -0.020 and -0.017 .

We next examine OLS estimates of human capital externalities by education level. Moretti (2004) shows that less skilled workers receive the largest human capital wage externalities and Manning (2004) suggests that less skilled workers are the primary beneficiaries

\footnotetext{
${ }^{21}$ The results for the two age structure variables are also qualitatively robust to excluding the other from the regressions.
} 
of consumption externalities on employment outcomes. We also suspect that less skilled individuals will receive larger external benefits of human capital on participation and employment. We separate individuals into four groups by education: 1) those with less than a high school degree, 2) those with a high school degree or equivalent but no college, 3) those with some college but without a four-year degree, and 4) those with a four-year college degree or higher. Table 4 presents OLS results for the external effects of human capital for the total population and for each of the four education groups separately for women and men. These results include all of the individual controls as well as the additional city-level controls. In the education group regressions the log wage variable is also education-specific. Each result is from a separate regression.

The results in Table 4 are consistent with the expectation that less skilled workers receive the largest human capital externalities on participation and employment. For women, the effect on LFP is largest for the two least educated groups, with coefficients of 0.411 and 0.344 . For women with some college the effect is still important with a coefficient of 0.199 , but for fouryear college graduates there is no significant effect on LFP. For men, the effects on LFP vary by education to a lesser extent. The two least educated groups have coefficients of 0.233 and 0.179 , while the two most educated groups have coefficients of 0.125 and 0.072 , all of which are statistically significant at the one percent level. The effects on the probability of employment are also decreasing in magnitude with education for both men and women and are statistically significant for all groups. ${ }^{22}$ The female coefficients for employment by education group are $0.536,0.427,0.265$, and 0.049 . These effects are very large for the two lowest education groups; the magnitudes suggest that a 0.10 increase in the college share externally increases the share of

\footnotetext{
22 These cross-sectional employment results are also consistent with Manning (2004) except that our results control for other city characteristics including the local wage.
} 
the female population with no college that is employed by more than 4 people per 100 . For men the employment coefficients by education are $0.382,0.275,0.192$, and 0.103 . Though smaller than the effects for women (except for college graduates), these are still large and meaningful effects.

The results thus far paint an interesting picture of external effects of human capital on labor force participation and employment. We view these as important relationships that have been largely overlooked. Importantly though, the local human capital level is unlikely to be exogenous. Workers sort into the labor market that gives them the highest utility and highly educated workers are generally the most mobile across areas. Thus while the results in Tables 2 , 3, and 4 are certainly interesting, we cannot be certain that the external effects of human capital are truly causal. We next pursue two complementary approaches intended to provide additional insight into the causal link between the local human capital level and employment externalities. Our first approach is to instrument for the local human capital level using the presence of a landgrant institution in the metropolitan area. Our second approach is to examine the relationship while controlling for time-invariant labor market characteristics using city fixed effects. Neither approach is definitive, but together they offer important insights.

\subsection{Pooled Cross-Section IV Results}

Table 5 presents the initial IV estimates of human capital externalities on labor force participation and employment. These regressions include all of the individual controls but not the city-level controls. The first stage results show that the land-grant variable is a significant predictor of the college share at the one percent level. The presence of a land-grant institution increases the share of adults with a four-year college degree by 0.063 . For the second stage results, the college share has a large and significantly positive effect on female participation and 
employment with coefficients of 0.370 and 0.433 . The IV estimates for men are much smaller and only the effect on employment is statistically significant with a coefficient of 0.128 .

Table 6 presents IV estimates of the external effects of human capital on labor force participation and employment with the additional city controls included and reports separate results by education level. The land-grant variable is again a significant predictor of the college share in the first stage with coefficients of 0.035 for women and 0.034 for men, but the coefficient is reduced compared to Table 5 because of the additional city level controls. The land-grant coefficients differ slightly by gender because the city-level wage variable included as a control is gender-specific. Although not shown, the land-grant coefficients also vary slightly in the education-specific regressions because in these regressions the wage variable is also education-specific. However, the land-grant coefficients for each gender by education group do not vary between the LFP and employment equations because the first-stage is the same for each.

Looking at the second stage results in Table 6, we see that the external effects of the local human capital level on female labor force participation are significantly increased relative to the OLS results in Table 4. The coefficient for the total population is 0.491 which is quite large. The female LFP coefficients are also quite large for each education group and are statistically significant for all groups. From the least educated to the most educated, the female LFP IV coefficients are $0.799,0.682,0.447$, and 0.228 . The result for female college graduates also differs from the OLS estimates where the coefficient was small and not statistically significant. For male LFP, the story is quite different from the OLS estimates. While the IV coefficients are positive for the total population and for all education groups, the effects on LFP are not statistically significant for any of the male groups. Thus the land-grant instrument suggests a 
strong positive external effect of the college share on female LFP but a much weaker and less consistent effect on male LFP.

The IV estimates suggest very large external effects of the college share on employment. For women the employment coefficient is 0.601 for the total population, suggesting that a 0.10 increase in the share of adults with a college degree increases female employment by more than 6.0 women per 100 . This is a very economically meaningful effect. The effects on female employment are also large and significant for each education group with coefficients of 1.040, $0.816,0.543$, and 0.271 . For men, the effects of the college share on employment are statistically significant for the total population and for each education group in contrast to the results for male LFP. The male employment coefficient for the total population is 0.229 and the coefficients by education group are $0.652,0.268,0.216$, and 0.081 .

The IV estimates, therefore, suggest large external effects of the local human capital level on employment for both sexes but considerably larger effects for women than men. The IV estimates for women are also twice the magnitude of the OLS estimates, while the IV and OLS for men are very similar. However, land grant institutions may have effects on their local labor markets beyond the effects of building the stock of college-educated labor. Land grants may have direct effects in improving local employment outcomes, and this may be especially true for women. For example, local women may be more likely than men to gain university employment in administrative and support positions. If there are direct effects, using land grants to instrument for the local human capital level may lead to upwardly biased estimates.

\subsection{City Fixed Effects Results}

Table 7 presents the results for the city fixed effects models that include the individual controls but not the additional city level controls. For women the college share has positive 
coefficients for both labor force participation and employment of 0.068 and 0.115 , but only the employment effect is statistically significant. These fixed effects coefficients for women are considerably smaller than their OLS and IV counterparts suggesting that time-invariant city characteristics may upwardly bias estimates without fixed effects. An alternative explanation is that the fixed effects may exacerbate potential issues with measurement error in the college share and attenuate coefficient estimates of human capital externalities. However, the male participation and employment fixed effects coefficients are significantly positive at 0.086 and 0.140 and only slightly reduced compared to the corresponding OLS estimates. This suggests that measurement error in the college share is likely a minor issue, or it would have reduced the male coefficients also. The reduction in the female coefficients is mostly due to controlling for time-invariant city characteristics. Interestingly, these time-invariant local characteristics benefit women considerably more than men similarly to how the IV estimates increased much more for women than men. Our most preferred estimates include city fixed effects.

Table 8 presents city fixed results that also include the additional city controls for both the total population and by education group. Including the city controls again increases the coefficient estimates. The results now suggest that the human capital level significantly increases female labor force participation for the total population with a coefficient of 0.151 . The female LFP fixed effects coefficients by education group are significant for all groups with coefficients of $0.228,0.230,0.176$, and 0.075 . For male LFP, the coefficient for the total population is 0.076 and statistically significant. The male LFP coefficients by education group are $-0.056,0.092,0.117$, and 0.084 and are statistically significant for the three most educated groups but negative (though not significant) for high school dropouts. 
We next examine the city fixed effects estimates of human capital externalities on employment. For females the human capital level has a statistically significant external effect on employment for the total population with a coefficient of 0.221 . The female employment coefficients from the least educated to the most educated are $0.327,0.322,0.246$, and 0.084 , all of which are statistically significant. Increases in the human capital level again increase male employment for the total population with a significant coefficient of 0.193 . The male employment coefficients by education group from the lowest to highest are $0.151,0.259,0.233$, and 0.120 , all of which are statistically significant. The city fixed effects results, therefore, provide considerable support for human capital externalities in general and human capital spillovers in particular.

We also experiment with controlling for the share of the elderly population (age 65 or over) with at least a four-year college degree as suggested by Manning (2004). According to Manning, since the elderly are less attached to the labor force, their human capital levels better measure consumption spillovers than human capital spillovers. Including the college share among the elderly to control for consumption externalities may allow us to better isolate the effect of human capital spillovers measured by the college share among prime age adults. Table 9 presents city fixed effects results that include the elderly college share as a city level control. The results are presented both without (Panel A) and with the additional city controls (Panel B). Including the elderly college share increases the coefficient for the prime age college share on female participation and employment, both with and without the additional city controls. Surprisingly, the elderly college share has a significantly negative effect on female participation and employment. For men, the coefficient for the prime age college share is still positive and significant and largely unchanged from the results in Tables 7 and 8 . The elderly 
college share has a significantly positive effect on male participation in Panel A but an insignificant negative effect in Panel B. For male employment the elderly college share has a significantly negative effect in both panels. Thus, while negative effects of the elderly college share were not expected, the main results for the prime age college share are qualitatively robust to its inclusion and support the existence of human capital spillovers. ${ }^{23}$

\section{Conclusion}

This paper investigates the extent to which the local level of human capital, as measured by the share of prime age adults with a college degree, has positive external effects on the probability of labor force participation and employment for residents of U.S. metro areas. Previous literature has given considerable attention to human capital externalities on wages, but the external effects on participation and employment have been largely overlooked. However, if working alongside skilled workers increases skill accumulation, the local human capital level is also likely to affect the probability of participation and employment.

We first document the external effects of human capital on participation and employment using pooled cross-section data from the 1980 and 2000 censuses and treating the local human capital level as exogenous. However, the local human capital level at a point in time may not be exogenous. We try to offer additional insights into the causal effects of human capital externalities on participation and employment using two approaches: 1) instrumenting for the local human capital level using the presence of a land grant institution in the area, and 2) controlling for time-invariant characteristics using city fixed effects. Neither is definitive, but

\footnotetext{
${ }^{23}$ Results are also qualitatively robust to measuring college shares based only on the employed population. In results not shown we also estimated equations that include the elderly college share but not the prime age college share. The elderly college share was still significantly negative in six of the eight specifications with city fixed effects. Given the difficulty interpreting this result, the preferred specifications do not include the elderly college share.
} 
together they provide some important results. The city fixed effects specifications provide the most conservative estimates and these are our preferred results.

This paper finds that the local human capital level has positive externalities on the probability of employment for both men and women, with slightly larger effects for women than men. Furthermore, the increased employment probability is largely due to increased labor force participation, especially for women. This is consistent with the hypothesis that individuals accumulate greater skills from working in labor markets alongside high human capital workers and these human capital spillovers increase the recipients' willingness to supply their labor to the market. There are also important differences by education level. Less educated individuals generally receive the largest external benefits and four-year college graduates often receive relatively little external benefit. 


\section{References}

Abel, J.R., Deitz, R. (2011) Do colleges and universities increase their region's human capital? Journal of Economic Geography, Forthcoming, doi:10.1093/jeg/lbr020.

Acemoglu, D. (1996) A microfoundation for social increasing returns in human capital accumulation. Quarterly Journal of Economics, 111: 779-804.

Armstrong, H., Taylor, J. (2000) Regional Economics and Policy, Third Edition. Oxford: Blackwell.

Bacolod, M., Blum, B., Strange, W.C. (2009) Skills and the city. Journal of Urban Economics, 65: 127-135.

Bacolod, M., Blum, B., Strange, W.C. (2010) Elements of skill: traits, intelligences, education, and agglomeration. Journal of Regional Science, 50: 245-280.

Berliant, M., Reed, R.R., Wang, P. (2006) Knowledge exchange, matching, and agglomeration. Journal of Urban Economics, 60: 69-95.

Berry, C.R., Glaeser, E.L. (2005) The divergence of human capital levels across cities. Papers in Regional Science, 84: 407-444.

Black, D., Kolesnikova, N., Taylor, L.J. (2008a) Why do so few women work in New York (and so many in Minneapolis)? labor supply of married women across U.S. cities. Federal Reserve Bank of St. Louis Working Paper 2007-043C.

Black, D., Kolesnikova, N., Taylor, L.J. (2008b) Local price variation and labor supply behavior. Federal Reserve Bank of St. Louis Working Paper 2008-016A.

Black, D., Henderson, V. (1999) A theory of urban growth. Journal of Political Economy, 107: 252-284. 
Blackaby, D.H., Manning, D.N. (1992) Regional earnings and unemployment - a simultaneous approach. Oxford Bulletin of Economics and Statistics, 54: 481-501.

Chen, Y., Rosenthal, S.S. (2008) Local amenities and life-cycle migration: do people move for jobs or fun? Journal of Urban Economics, 64: 519-537.

Ciccone, A., Peri, G. (2006) Identifying human capital externalities: theory with applications. Review of Economic Studies, 73: 381-412.

Combes, P.P., Duranton, G., Gobillon, L. (2008) Spatial wage disparities: sorting matters! Journal of Urban Economics, 63: 723-742.

Compton, J., Pollak, R. (2011) Family proximity, childcare and women's labor force attachment. NBER Working Paper No. 17678.

Dalmazzo, A., de Blasio, G. (2007a) Production and consumption externalities of human capital: an empirical study for Italy. Journal of Population Economics, 20: 359-382.

Dalmazzo, A., de Blasio, G. (2007b) Social returns to education in Italian local labor markets. Annals of Regional Science, 41: 51-69.

Diamond, C.A., Simon, C.J. (1990) Industrial specialization and the returns to labor. Journal of Labor Economics, 8: 175-201.

Doms, M., Lewis, E., Robb, A. (2010) Local labor force education, new business characteristics, and firm performance. Journal of Urban Economics, 67: 61-77.

Elhorst, J.P. (1995) Unemployment disparities between regions in the European Union. In H.W. Armstrong, R.W. Vickerman (eds.), Convergence and Divergence among European Unions, London: Pion.

Elhorst, J.P. (2003) The Mystery of regional unemployment differentials: theoretical and empirical explanations. Journal of Economic Surveys, 17: 709-748. 
Florida, R. (2002) Bohemia and economic geography. Journal of Economic Geography, 2: 5571.

Florida, R., Mellander, C., Stolarick, K. (2008) Inside the black box of regional developmenthuman capital, the creative class, and tolerance. Journal of Economic Geography, 8: 615649.

Fu, S. (2007) Smart café cities: testing human capital externalities in the Boston Metropolitan Area. Journal of Urban Economics, 61: 86-111.

Glaeser, E.L. (1999) Learning in cities. Journal of Urban Economics, 46: 254-277.

Glaeser, E.L. (2010) Teach your neighbors well. New York Times blog post on March 30, 2010, Accessed on April 10, 2010.

Glaeser, E.L., Maré, D.C. (2001) Cities and skills. Journal of Labor Economics, 19: 316-342.

Glaeser, E.L., Saiz, A. (2004) The rise of the skilled city. Brookings-Wharton Papers on Urban Affairs: 47-94.

Glaeser, E.L., Scheinkman, J.A., Shleifer, A. (1995) Economic growth in a cross-section of cities. Journal of Monetary Economics, 36: 117-143.

Henderson, J.V. (2007) Understanding knowledge spillovers. Regional Science and Urban Economics, 37: 497-508.

Iranzo, S., Peri, G. (2009) Schooling externalities, technology, and productivity: theory and evidence from U.S. states. Review of Economics and Statistics, 91: 420-431.

Johnson, W.R. (2009) House prices and female labor force participation. University of Virginia Working Paper.

Jovanovic, B., Rob, R. (1989) The growth and diffusion of knowledge. Review of Economic Studies, 56: 569-582. 
Juhn, C., Murphy, K.M., Topel, R.H. (1991) Why has the natural rate of unemployment increased over time? Brookings Papers on Economic Activity, 1991: 75-126.

Juhn, C., Murphy, K.M., Topel, R.H. (2002) Current unemployment, historically contemplated. Brookings Papers on Economic Activity, 2002: 79-116.

Kaplanis, A. (2010) Local human capital and its impact on local employment chances in Britain. SERC Discussion Paper 40.

Katz, L.F., Murphy, K.M. (1992) Changes in relative wages, 1963-1987: supply and demand factors. Quarterly Journal of Economics, 107: 35-78.

Lange, F., Topel, R. (2006) The social value of education and human capital. In E. Hanushek, F. Welch (eds.), Handbook of the Economics of Education. Amsterdam: Elsevier.

Lochner, L., Moretti, E. (2004) The effect of education on crime: evidence from prison inmates, arrests, and self-reports. American Economic Review, 94: 155-189.

Manning, A. (2004) We can work it out: the impact of technological change on the demand for low-skill workers. Scottish Journal of Political Economy, 51: 581-608.

Mazzolari, F., Ragusa, G. (2011) Spillovers from high-skill consumption to low-skill labor markets. Review of Economics and Statistics, Forthcoming, doi:10.1162/REST_a_00234.

Milligan, K., Moretti, E., Oreopoulos, P. (2004) Does education improve citizenship? evidence from the U.S. and the U.K. Journal of Public Economics, 88: 1667-1695.

Moomaw, R.L. (1998) Experience rating and the generosity of unemployment insurance: effects on county and metropolitan unemployment rates. Journal of Labor Research, 19: 543560.

Moretti, E. (2004a) Estimating the social return to higher education: evidence from longitudinal and repeated cross-sectional data. Journal of Econometrics, 121: 175-212. 
Moretti, E. (2004b) Human capital externalities in cities. In J. V. Henderson, J.F. Thisse (eds.), Handbook of Regional and Urban Economics. Amsterdam: Elsevier.

Neumann, G.R., Topel, R.H. (1991) Employment risk, diversification, and unemployment. Quarterly Journal of Economics, 106: 1341-1365.

Nistor, A. (2009) Assessing the effectiveness of human capital investments on the regional unemployment rate in the United States: 1990 and 2000. International Regional Science Review, 32: 65-91.

Partridge, M.D., Rickman, D.S. (1995) Differences in state unemployment rates: the role of labor and product market structural shifts. Southern Economic Journal, 62: 89-106.

Partridge, M.D., Rickman, D.S. (1997) The dispersion in US state unemployment rates: the role of market and non-market equilibrium factors. Regional Studies, 31: 593-606.

Psacharopoulos, G., Patrinos, H.A. (2004) Returns to investment in education: a further update. Education Economics, 12: 111-134.

Rauch, J.E. (1993) Productivity gains from geographic concentration of human capital: evidence from the cities. Journal of Urban Economics, 34: 380-400.

Rosenthal, S.S., Strange, W.C. (2008) The attenuation of human capital spillovers. Journal of Urban Economics, 64: 373-389.

Ruggles, S., Sobek, M., Alexander, T., Fitch, C.A., Goeken, R., Hall, P.K., King, M., Ronnander, C. (2008) Integrated Public Use Microdata Series: Version 4.0 [Machine-readable database]. Minneapolis, MN: Minnesota Population Center [producer and distributor].

Shapiro, J.M. (2006) Smart cities: quality of life, productivity, and the growth effects of human capital. Review of Economics and Statistics, 88: 324-335. 
Shimer, R. (2001) The impact of young workers on the aggregate labor market. Quarterly Journal of Economics, 116: 969-1007.

Simon, C.J. (1988) Frictional unemployment and the role of industrial diversity. Quarterly Journal of Economics, 103: 715-728.

Simon, C.J. (1998) Human capital and metropolitan employment growth. Journal of Urban Economics, 43: 223-243.

Simon, C.J. (2004) Industrial reallocation across U.S. cities, 1977-97. Journal of Urban Economics, 56: 119-143.

Simon, C.J., Nardinelli, C. (2002) Human capital and the rise of American cities, 1900-1990. Regional Science and Urban Economics, 32: 59-96.

Wheeler, C.H. (2001) Search, sorting, and urban agglomeration. Journal of Labor Economics, 19: 879-899.

Wheeler, C.H. (2006) Cities and the growth of wages among young workers: evidence from the NLSY. Journal of Urban Economics, 60: 162-184.

Winters, J.V. (2009) Wages and prices: are workers fully compensated for cost of living differences? Regional Science and Urban Economics, 39: 632-643.

Winters, J.V. (2011a) Human capital, higher education institutions, and quality of life. Regional Science and Urban Economics, 41: 446-454.

Winters, J.V. (2011b) Why are smart cities growing? who moves and who stays. Journal of Regional Science, 51: 253-270.

Wozniak, A. (2010) Are college graduates more responsive to distant labor market opportunities? Journal of Human Resources, 45: 944-970. 
Table 1: Summary Statistics for Metropolitan-Level Variables

\begin{tabular}{|c|c|c|c|c|c|c|}
\hline & \multicolumn{2}{|c|}{1980} & \multicolumn{2}{|c|}{2000} & \multicolumn{2}{|c|}{$\Delta$ 1980-2000 } \\
\hline & & Std. & & Std. & & Std. \\
\hline & Mean & Dev. & Mean & Dev. & Mean & Dev. \\
\hline$\%$ of Females in Labor Force, Total Population & 0.630 & 0.053 & 0.744 & 0.049 & 0.114 & 0.046 \\
\hline$\%$ of Females in Labor Force, Less than High School & 0.506 & 0.071 & 0.540 & 0.066 & 0.034 & 0.069 \\
\hline$\%$ of Females in Labor Force, High School Graduate & 0.632 & 0.055 & 0.714 & 0.050 & 0.081 & 0.053 \\
\hline$\%$ of Females in Labor Force, Some College & 0.676 & 0.047 & 0.784 & 0.038 & 0.109 & 0.048 \\
\hline$\%$ of Females in Labor Force, Bachelor's or Higher & 0.751 & 0.040 & 0.828 & 0.033 & 0.077 & 0.044 \\
\hline$\%$ of Females Employed, Total Population & 0.596 & 0.057 & 0.713 & 0.056 & 0.116 & 0.051 \\
\hline$\%$ of Females Employed, Less than High School & 0.459 & 0.075 & 0.479 & 0.071 & 0.020 & 0.070 \\
\hline$\%$ of Females Employed, High School Graduate & 0.599 & 0.060 & 0.678 & 0.056 & 0.079 & 0.059 \\
\hline$\%$ of Females Employed, Some College & 0.646 & 0.051 & 0.757 & 0.043 & 0.111 & 0.052 \\
\hline$\%$ of Females Employed, Bachelor's or Higher & 0.732 & 0.041 & 0.813 & 0.034 & 0.081 & 0.046 \\
\hline$\%$ of Males in Labor Force, Total Population & 0.926 & 0.025 & 0.862 & 0.040 & -0.064 & 0.034 \\
\hline$\%$ of Males in Labor Force, Less than High School & 0.854 & 0.044 & 0.698 & 0.074 & -0.155 & 0.069 \\
\hline$\%$ of Males in Labor Force, High School Graduate & 0.943 & 0.022 & 0.842 & 0.044 & -0.100 & 0.036 \\
\hline$\%$ of Males in Labor Force, Some College & 0.938 & 0.028 & 0.892 & 0.033 & -0.046 & 0.033 \\
\hline$\%$ of Males in Labor Force, Bachelor's or Higher & 0.963 & 0.024 & 0.941 & 0.021 & -0.022 & 0.023 \\
\hline$\%$ of Males Employed, Total Population & 0.882 & 0.033 & 0.827 & 0.047 & -0.055 & 0.040 \\
\hline$\%$ of Males Employed, Less than High School & 0.779 & 0.055 & 0.632 & 0.079 & -0.147 & 0.073 \\
\hline$\%$ of Males Employed, High School Graduate & 0.895 & 0.032 & 0.801 & 0.050 & -0.095 & 0.047 \\
\hline$\%$ of Males Employed, Some College & 0.899 & 0.035 & 0.862 & 0.036 & -0.037 & 0.040 \\
\hline$\%$ of Males Employed, Bachelor's or Higher & 0.947 & 0.026 & 0.925 & 0.023 & -0.022 & 0.025 \\
\hline$\%$ of Prime Age with Bachelor's or Higher & 0.197 & 0.059 & 0.264 & 0.080 & 0.067 & 0.038 \\
\hline Ln Wage FE Females & 0.143 & 0.078 & 0.193 & 0.111 & 0.051 & 0.072 \\
\hline Ln Wage FE Males & 0.166 & 0.109 & 0.182 & 0.109 & 0.015 & 0.081 \\
\hline Ln Rent FE & 0.014 & 0.158 & 0.142 & 0.217 & 0.127 & 0.118 \\
\hline Mean Commute Time & 19.30 & 3.06 & 22.98 & 3.79 & 3.68 & 1.97 \\
\hline Ln Employment Density & 3.791 & 0.944 & 4.181 & 0.910 & 0.390 & 0.201 \\
\hline Predicted Unemployment Rate & 0.059 & 0.003 & 0.050 & 0.002 & -0.009 & 0.003 \\
\hline Industry Herfindahl Index & 0.159 & 0.032 & 0.154 & 0.023 & -0.005 & 0.024 \\
\hline$\%$ of Population Age $16-24$ & 0.179 & 0.035 & 0.134 & 0.036 & -0.045 & 0.019 \\
\hline$\%$ of Population Age $65+$ & 0.107 & 0.029 & 0.125 & 0.030 & 0.017 & 0.018 \\
\hline Ln Unemployment Insurance Benefits & 3.534 & 0.483 & 4.633 & 0.411 & 1.099 & 0.419 \\
\hline
\end{tabular}

Notes: Sample includes 283 metropolitan areas. LFP, Employment, Bachelor's degree shares and Ln Wage FEs are computed based on the population ages 25-55. 
Table 2: OLS Estimates of Human Capital Externalities without City Level Controls

\begin{tabular}{|c|c|c|c|c|}
\hline & \multicolumn{2}{|c|}{ Women } & \multicolumn{2}{|c|}{ Men } \\
\hline & LFP & Employment & LFP & Employment \\
\hline$\%$ of Prime Age with Bachelor's or Higher & $\begin{array}{c}0.181 * * * \\
(0.028)\end{array}$ & $\begin{array}{c}0.225 * * * \\
(0.033)\end{array}$ & $\begin{array}{c}0.097 * * * \\
(0.021)\end{array}$ & $\begin{array}{c}0.153 * * * \\
(0.027)\end{array}$ \\
\hline Individual Observations & \multicolumn{2}{|c|}{$3,980,559$} & \multicolumn{2}{|c|}{$3,813,115$} \\
\hline
\end{tabular}


Table 3: OLS Estimates of Human Capital Externalities with City Level Controls

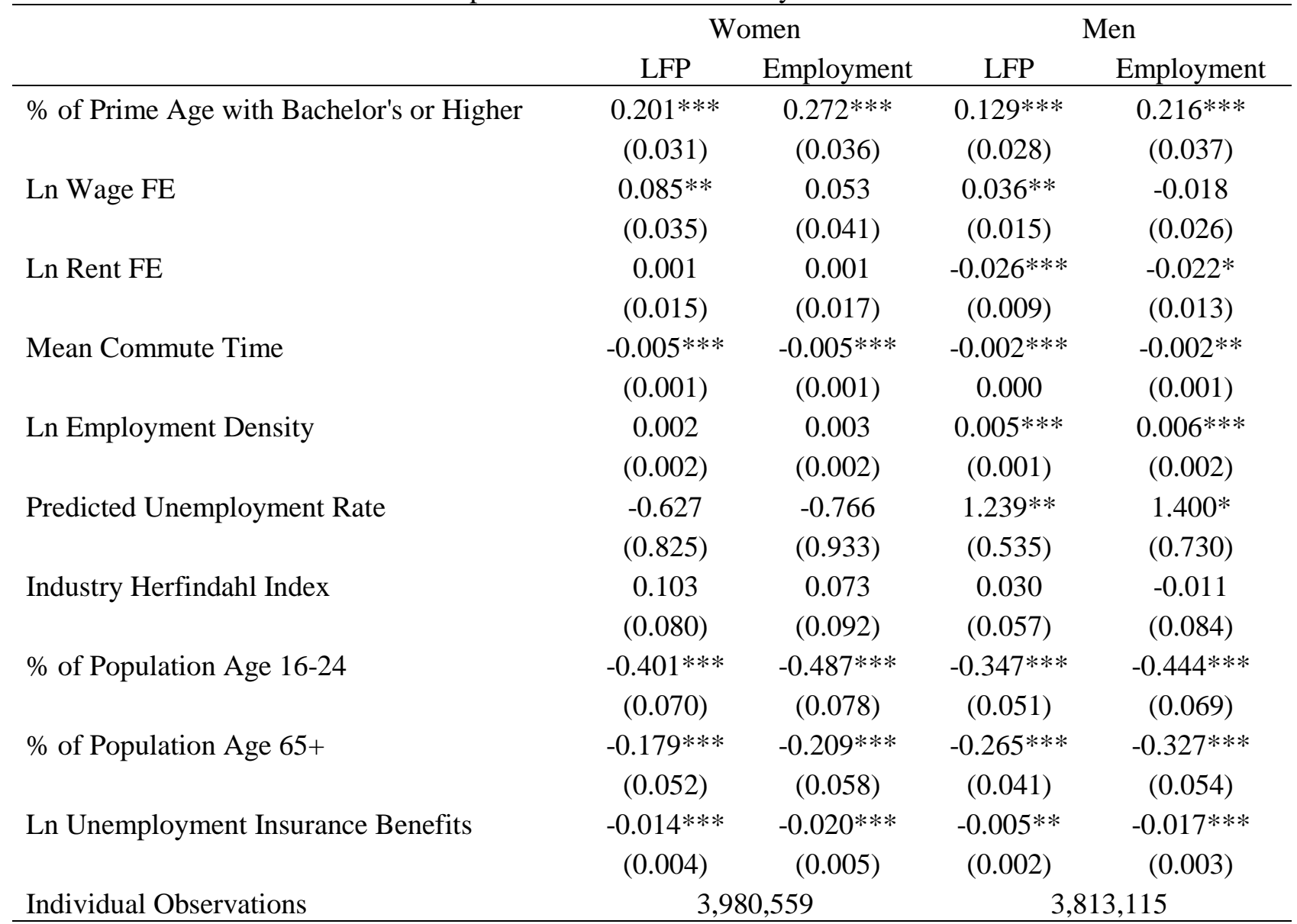

Notes: Regressions are for a pooled cross-section of individuals from 283 metro areas in 1980 and 2000 and include individual level controls. Standard errors in parentheses are clustered by metropolitan areayear.

*Significant at 10\%; **Significant at 5\%; ***Significant at $1 \%$. 
Table 4: OLS Estimates of Human Capital Externalities with City Controls by Education Level

\begin{tabular}{lcccc}
\hline & \multicolumn{2}{c}{ Women } & \multicolumn{2}{c}{ Men } \\
& LFP & Employment & LFP & Employment \\
\hline Total Population & $0.201 * * *$ & $0.272^{* * *}$ & $0.129 * * *$ & $0.216^{* * *}$ \\
& $(0.031)$ & $(0.036)$ & $(0.028)$ & $(0.037)$ \\
Less than High School & $0.411^{* * *}$ & $0.536^{* * *}$ & $0.233^{* * *}$ & $0.382^{* * *}$ \\
& $(0.062)$ & $(0.065)$ & $(0.061)$ & $(0.074)$ \\
High School Graduate & $0.344 * * *$ & $0.427 * * *$ & $0.179^{* * *}$ & $0.275^{* * *}$ \\
& $(0.043)$ & $(0.049)$ & $(0.040)$ & $(0.048)$ \\
Some College & $0.199 * * *$ & $0.265^{* * *}$ & $0.125^{* * *}$ & $0.192 * * *$ \\
& $(0.030)$ & $(0.034)$ & $(0.024)$ & $(0.033)$ \\
Bachelor's or Higher & 0.024 & $0.049 * *$ & $0.072 * * *$ & $0.103 * * *$ \\
& $(0.021)$ & $(0.022)$ & $(0.017)$ & $(0.022)$ \\
\hline
\end{tabular}

Notes: Regressions are for a pooled cross-section of individuals from 283 metro areas in 1980 and 2000 and include individual and city level controls. Standard errors in parentheses are clustered by metropolitan area-year.

** Significant at 5\%; ***Significant at $1 \%$. 
Table 5: IV Estimates of Human Capital Externalities without City Level Controls

\begin{tabular}{|c|c|c|c|c|}
\hline & \multicolumn{2}{|c|}{ Women } & \multicolumn{2}{|c|}{ Men } \\
\hline & LFP & Employment & LFP & Employment \\
\hline \multicolumn{5}{|l|}{ First Stage } \\
\hline Land Grant & $\begin{array}{c}0.063 * * * \\
(0.016)\end{array}$ & $\begin{array}{c}0.063 * * * \\
(0.016)\end{array}$ & $\begin{array}{c}0.063 * * * \\
(0.016)\end{array}$ & $\begin{array}{c}0.063 * * * \\
(0.016)\end{array}$ \\
\hline \multicolumn{5}{|l|}{$\underline{\text { Second Stage }}$} \\
\hline$\%$ of Prime Age with Bachelor's or Higher & $\begin{array}{c}0.370 * * * \\
(0.086)\end{array}$ & $\begin{array}{c}0.433 * * * \\
(0.096)\end{array}$ & $\begin{array}{c}0.047 \\
(0.054)\end{array}$ & $\begin{array}{c}0.128 * * \\
(0.065)\end{array}$ \\
\hline Individual Observations & \multicolumn{2}{|c|}{$3,980,559$} & \multicolumn{2}{|c|}{$3,813,115$} \\
\hline
\end{tabular}


Table 6: IV Estimates of Human Capital Externalities with City Controls by Education Level

\begin{tabular}{lcccc}
\hline & \multicolumn{2}{c}{ Women } & \multicolumn{2}{c}{ Men } \\
& LFP & Employment & LFP & Employment \\
\hline First Stage & & & & \\
Land Grant & $0.035^{* * *}$ & $0.035^{* * *}$ & $0.034^{* * *}$ & $0.034 * * *$ \\
& $(0.009)$ & $(0.009)$ & $(0.009)$ & $(0.009)$ \\
\hline Second Stage & & & & \\
Total Population & $0.491^{* * *}$ & $0.601 * * *$ & 0.095 & $0.229^{* *}$ \\
& $(0.149)$ & $(0.168)$ & $(0.078)$ & $(0.103)$ \\
Less than High School & $0.799^{* *}$ & $1.040^{* * *}$ & 0.231 & $0.652^{* *}$ \\
& $(0.339)$ & $(0.388)$ & $(0.202)$ & $(0.308)$ \\
High School Graduate & $0.682^{* * *}$ & $0.816^{* * *}$ & 0.063 & $0.268^{* *}$ \\
& $(0.196)$ & $(0.216)$ & $(0.098)$ & $(0.130)$ \\
Some College & $0.447^{* * *}$ & $0.543^{* * *}$ & 0.068 & $0.216^{* *}$ \\
& $(0.133)$ & $(0.150)$ & $(0.067)$ & $(0.089)$ \\
Bachelor's or Higher & $0.228^{* * *}$ & $0.271^{* * *}$ & 0.045 & $0.081^{*}$ \\
& $(0.076)$ & $(0.084)$ & $(0.040)$ & $(0.047)$ \\
\hline Notes: Regresion
\end{tabular}

Notes: Regressions are for a pooled cross-section of individuals from 283 metro areas in 1980 and 2000 and include individual and city level controls. Standard errors in parentheses are clustered by metropolitan area-year.

*Significant at $10 \%$;* Significant at 5\%;***Significant at $1 \%$. 
Table 7: City Fixed Effects Estimates of Human Capital Externalities without City Level Controls

\begin{tabular}{lcccc}
\hline & \multicolumn{2}{c}{ Women } & \multicolumn{2}{c}{ Men } \\
& LFP & Employment & LFP & Employment \\
\hline \% of Prime Age with Bachelor's or Higher & 0.068 & $0.115^{* *}$ & $0.086^{* * *}$ & $0.140^{* * *}$ \\
& $(0.049)$ & $(0.057)$ & $(0.031)$ & $(0.042)$ \\
Individual Observations & \multicolumn{2}{c}{$3,980,559$} & \multicolumn{2}{c}{$3,813,115$} \\
\hline
\end{tabular}

Notes: Regressions are for a pooled cross-section of individuals from 283 metro areas in 1980 and 2000 and include individual level controls. Standard errors in parentheses are clustered by metropolitan areayear.

**Significant at 5\%; ***Significant at $1 \%$. 
Table 8: City FE Estimates of Human Capital Externalities with City Controls by Education Level

\begin{tabular}{lcccc}
\hline & \multicolumn{2}{c}{ Women } & \multicolumn{2}{c}{ Men } \\
& LFP & Employment & LFP & Employment \\
\hline Total Population & $0.151^{* * *}$ & $0.221^{* * *}$ & $0.076^{* * *}$ & $0.193^{* * *}$ \\
& $(0.058)$ & $(0.067)$ & $(0.027)$ & $(0.043)$ \\
Less than High School & $0.228^{* * *}$ & $0.327 * * *$ & -0.056 & $0.151^{*}$ \\
& $(0.080)$ & $(0.088)$ & $(0.065)$ & $(0.080)$ \\
High School Graduate & $0.230^{* * *}$ & $0.322^{* * *}$ & $0.092^{* *}$ & $0.259^{* * *}$ \\
& $(0.071)$ & $(0.077)$ & $(0.041)$ & $(0.060)$ \\
Some College & $0.176^{* * *}$ & $0.246^{* * *}$ & $0.117^{* * *}$ & $0.233^{* * *}$ \\
& $(0.067)$ & $(0.080)$ & $(0.029)$ & $(0.048)$ \\
Bachelor's or Higher & $0.075^{*}$ & $0.084 *$ & $0.084 * * *$ & $0.120^{* * *}$ \\
& $(0.041)$ & $(0.047)$ & $(0.020)$ & $(0.024)$ \\
\hline
\end{tabular}

Notes: Regressions are for a pooled cross-section of individuals from 283 metro areas in 1980 and 2000 and include individual and city level controls. Standard errors in parentheses are clustered by metropolitan area-year.

*Significant at 10\%; **Significant at 5\%; ***Significant at $1 \%$. 
Table 9: City FE Estimates Including the Elderly College Share as a City Level Control

\begin{tabular}{|c|c|c|c|c|}
\hline & \multicolumn{2}{|c|}{ Women } & \multicolumn{2}{|c|}{ Men } \\
\hline & LFP & Employment & LFP & Employment \\
\hline \multicolumn{5}{|l|}{ A. Without Additional City Controls } \\
\hline$\%$ of Prime Age with Bachelor's or Higher & $\begin{array}{c}0.133 * * \\
(0.055)\end{array}$ & $\begin{array}{c}0.205 * * * \\
(0.064)\end{array}$ & $\begin{array}{c}0.069 * * \\
(0.033)\end{array}$ & $\begin{array}{c}0.171 * * * \\
(0.047)\end{array}$ \\
\hline$\%$ of Elderly with Bachelor's or Higher & $\begin{array}{c}-0.254 * * * \\
(0.072)\end{array}$ & $\begin{array}{c}-0.350 * * * \\
(0.087)\end{array}$ & $\begin{array}{l}0.065^{*} \\
(0.038)\end{array}$ & $\begin{array}{c}-0.117 * * \\
(0.059)\end{array}$ \\
\hline \multicolumn{5}{|l|}{ B. With Additional City Controls } \\
\hline$\%$ of Prime Age with Bachelor's or Higher & $\begin{array}{c}0.160 * * * \\
(0.054)\end{array}$ & $\begin{array}{c}0.232 * * * \\
(0.063)\end{array}$ & $\begin{array}{c}0.087 * * * \\
(0.027)\end{array}$ & $\begin{array}{c}0.221 * * * \\
(0.042)\end{array}$ \\
\hline$\%$ of Elderly with Bachelor's or Higher & $\begin{array}{c}-0.202 * * * \\
(0.077)\end{array}$ & $\begin{array}{c}-0.255^{* * *} * \\
(0.092)\end{array}$ & $\begin{array}{l}-0.043 \\
(0.041)\end{array}$ & $\begin{array}{c}-0.130 * * \\
(0.057)\end{array}$ \\
\hline Individual Observations & \multicolumn{2}{|c|}{$3,980,559$} & \multicolumn{2}{|c|}{$3,813,115$} \\
\hline
\end{tabular}


Appendix Table A: Summary Statistics and OLS Coefficients for Individual Characteristics with City Controls

\begin{tabular}{|c|c|c|c|c|c|c|c|c|}
\hline & \multicolumn{4}{|c|}{ Summary Statistics } & \multicolumn{4}{|c|}{ Regression Coefficients } \\
\hline & \multicolumn{2}{|c|}{ Women } & \multicolumn{2}{|c|}{ Men } & \multicolumn{2}{|c|}{ Women } & \multicolumn{2}{|c|}{ Men } \\
\hline & Mean & S.D. & Mean & S.D. & LFP & Employment & LFP & Employment \\
\hline Highest Grade 5-6 & 0.017 & 0.128 & 0.019 & 0.138 & $0.063 * * *$ & $0.056 * * *$ & $0.088 * * *$ & $0.077 * * *$ \\
\hline Highest Grade 5-6, 2000 & 0.009 & 0.092 & 0.010 & 0.102 & -0.008 & 0.006 & 0.006 & $0.028 * * *$ \\
\hline Highest Grade 7-8 & 0.028 & 0.164 & 0.032 & 0.175 & $0.062 * * *$ & $0.055 * * *$ & $0.104 * * *$ & $0.085 * * *$ \\
\hline Highest Grade 7-8, 2000 & 0.008 & 0.091 & 0.010 & 0.100 & $-0.062 * * *$ & $-0.053 * * *$ & $-0.060 * * *$ & $-0.032 * *$ \\
\hline Highest Grade 9 & 0.026 & 0.158 & 0.026 & 0.159 & $0.095 * * *$ & $0.086^{* * *}$ & $0.125^{* * *}$ & $0.105 * * *$ \\
\hline Highest Grade 9, 2000 & 0.010 & 0.098 & 0.011 & 0.106 & $-0.078 * * *$ & $-0.066^{* * *}$ & $-0.068 * * *$ & $-0.040 * * *$ \\
\hline Highest Grade 10 & 0.034 & 0.180 & 0.032 & 0.176 & $0.125 * * *$ & $0.116^{* * *}$ & $0.138 * * *$ & $0.120 * * *$ \\
\hline Highest Grade 10, 2000 & 0.012 & 0.107 & 0.013 & 0.115 & $-0.094 * * *$ & $-0.088 * * *$ & $-0.065 * * *$ & $-0.047 * * *$ \\
\hline Highest Grade 11 & 0.052 & 0.223 & 0.054 & 0.227 & $0.163 * * *$ & $0.155^{* * *}$ & $0.155^{* * *}$ & $0.140 * * *$ \\
\hline Highest Grade 11, 2000 & 0.031 & 0.173 & 0.037 & 0.188 & $-0.085 * * *$ & $-0.075^{* * *}$ & $-0.046 * * *$ & $-0.027 *$ \\
\hline Highest Grade 12 & 0.312 & 0.463 & 0.275 & 0.447 & $0.251 * * *$ & $0.254 * * *$ & $0.187 * * *$ & $0.194 * * *$ \\
\hline Highest Grade 12, 2000 & 0.147 & 0.354 & 0.149 & 0.356 & $-0.053 * * *$ & $-0.034 * *$ & 0.007 & 0.025 \\
\hline One Year of College & 0.180 & 0.384 & 0.166 & 0.372 & $0.295 * * *$ & $0.300 * * *$ & $0.184 * * *$ & $0.199 * * *$ \\
\hline One Year of College, 2000 & 0.134 & 0.340 & 0.126 & 0.332 & $-0.028 * *$ & -0.005 & $0.053 * * *$ & $0.072 * * *$ \\
\hline Two Year Degree & 0.097 & 0.297 & 0.096 & 0.294 & $0.311 * * *$ & $0.322 * * *$ & $0.193 * * *$ & $0.217 * * *$ \\
\hline Two Year Degree, 2000 & 0.049 & 0.215 & 0.040 & 0.195 & -0.008 & 0.016 & $0.060 * * *$ & $0.076 * * *$ \\
\hline Bachelor's Degree & 0.165 & 0.371 & 0.178 & 0.383 & $0.353 * * *$ & $0.367 * * *$ & $0.211^{* * *}$ & $0.247 * * *$ \\
\hline Bachelor's Degree, 2000 & 0.110 & 0.312 & 0.108 & 0.310 & $-0.037 * *$ & -0.013 & $0.064 * * *$ & $0.073 * * *$ \\
\hline Master's Degree & 0.051 & 0.219 & 0.053 & 0.225 & $0.429 * * *$ & $0.444 * * *$ & $0.203 * * *$ & $0.242 * * *$ \\
\hline Master's Degree, 2000 & 0.040 & 0.197 & 0.038 & 0.191 & $-0.055 * * *$ & $-0.031 * *$ & $0.078 * * *$ & $0.084 * * *$ \\
\hline Professional Degree & 0.015 & 0.120 & 0.027 & 0.161 & $0.395 * * *$ & $0.414 * * *$ & $0.179 * * *$ & $0.223 * * *$ \\
\hline Professional Degree, 2000 & 0.010 & 0.102 & 0.016 & 0.125 & -0.018 & -0.001 & $0.102 * * *$ & $0.107 * * *$ \\
\hline Doctorate Degree & 0.008 & 0.088 & 0.022 & 0.147 & $0.456 * * *$ & $0.474 * * *$ & $0.226 * * *$ & $0.267 * * *$ \\
\hline Doctorate Degree, 2000 & 0.004 & 0.062 & 0.007 & 0.085 & $-0.037 * *$ & -0.016 & $0.063 * * *$ & $0.069 * * *$ \\
\hline Age Group 30-34 & 0.179 & 0.383 & 0.182 & 0.386 & $-0.017 * * *$ & $-0.010 * * *$ & 0.001 & $0.010 * * *$ \\
\hline Age Group 30-34, 2000 & 0.093 & 0.290 & 0.095 & 0.294 & $0.008 * * *$ & $0.005^{* *}$ & $-0.009 * * *$ & $-0.015 * * *$ \\
\hline Age Group 35-39 & 0.172 & 0.377 & 0.173 & 0.378 & $-0.016 * * *$ & -0.003 & $-0.002 *$ & $0.015 * * *$ \\
\hline Age Group 35-39, 2000 & 0.104 & 0.305 & 0.105 & 0.307 & 0.000 & $-0.005^{*}$ & $-0.017 * * *$ & $-0.032 * * *$ \\
\hline Age Group 40-44 & 0.159 & 0.365 & 0.159 & 0.366 & $-0.010 * * *$ & $0.006 * *$ & $-0.006 * * *$ & $0.016^{* * *}$ \\
\hline Age Group 40-44, 2000 & 0.102 & 0.303 & 0.103 & 0.304 & $-0.006 * *$ & $-0.014 * * *$ & $-0.021 * * *$ & $-0.041 * * *$ \\
\hline Age Group 45-49 & 0.146 & 0.353 & 0.144 & 0.351 & $-0.045^{* * *}$ & $-0.027 * * *$ & $-0.015 * * *$ & $0.009 * * *$ \\
\hline Age Group 45-49, 2000 & 0.092 & 0.289 & 0.092 & 0.289 & $0.025 * * *$ & $0.017 * * *$ & $-0.020 * * *$ & $-0.043 * * *$ \\
\hline Age Group 50-55 & 0.095 & 0.293 & 0.093 & 0.290 & $-0.117 * * *$ & $-0.095^{* * *}$ & $-0.042 * * *$ & $-0.013 * * *$ \\
\hline Age Group 50-55, 2000 & 0.164 & 0.370 & 0.159 & 0.365 & $0.055^{* * *}$ & $0.049 * * *$ & $-0.017 * * *$ & $-0.042 * * *$ \\
\hline Married & 0.666 & 0.472 & 0.678 & 0.467 & $-0.054 * * *$ & $-0.042 * * *$ & $0.076^{* * *}$ & $0.107 * * *$ \\
\hline Married, 2000 & 0.362 & 0.481 & 0.367 & 0.482 & $0.030 * * *$ & $0.031 * * *$ & $-0.045 * * *$ & $-0.056 * * *$ \\
\hline Non-Wage Income & 33376 & 48294 & 19772 & 34732 & $-0.000 * * *$ & $-0.000 * * *$ & $-0.000 * * *$ & $-0.000 * * *$ \\
\hline Non-Wage Income, 2000 & 25558 & 50465 & 15998 & 35374 & $0.000 * * *$ & $0.000 * * *$ & $0.000 * * *$ & $0.000 * * *$ \\
\hline Has a Child & 0.627 & 0.483 & 0.527 & 0.499 & 0.004 & 0.000 & $0.040 * * *$ & $0.047 * * *$ \\
\hline Has a Child, 2000 & 0.341 & 0.474 & 0.282 & 0.450 & $0.039 * * *$ & $0.049 * * *$ & $0.023 * * *$ & $0.027 * * *$ \\
\hline Has a Child Age $<5$ & 0.182 & 0.386 & 0.182 & 0.386 & $-0.095 * * *$ & $-0.095 * * *$ & $-0.005 * * *$ & $-0.006 * * *$ \\
\hline
\end{tabular}




\begin{tabular}{|c|c|c|c|c|c|c|c|c|}
\hline Has a Child Age $<5,2000$ & 0.101 & 0.302 & 0.098 & 0.297 & $0.057 * * *$ & $0.055^{* * *}$ & $-0.005^{* *}$ & -0.003 \\
\hline Number of Children & 1.280 & 1.305 & 1.085 & 1.285 & $-0.023 * * *$ & $-0.024 * * *$ & $0.002 * * *$ & 0.000 \\
\hline Number of Children, 2000 & 0.665 & 1.097 & 0.558 & 1.039 & $0.003 * *$ & 0.001 & 0.001 & $0.002^{* *}$ \\
\hline$\#$ of Children Age $<5$ & 0.231 & 0.535 & 0.234 & 0.544 & $-0.115 * * *$ & $-0.109 * * *$ & $-0.006 * * *$ & $-0.008 * * *$ \\
\hline \# of Children Age $<5,2000$ & 0.129 & 0.417 & 0.126 & 0.417 & $0.029 * * *$ & $0.025 * * *$ & 0.003 & $0.003 *$ \\
\hline Black & 0.125 & 0.331 & 0.108 & 0.310 & $0.043 * * *$ & $0.021 * * *$ & $-0.065 * * *$ & $-0.093 * * *$ \\
\hline Black, 2000 & 0.072 & 0.258 & 0.062 & 0.241 & $-0.065 * * *$ & $-0.071 * * *$ & $-0.059 * * *$ & $-0.062 * * *$ \\
\hline Asian & 0.038 & 0.192 & 0.036 & 0.186 & $0.034 * *$ & $0.035^{* *}$ & $-0.040 * * *$ & $-0.038 * * *$ \\
\hline Asian, 2000 & 0.028 & 0.166 & 0.027 & 0.161 & $-0.080 * * *$ & $-0.084 * * *$ & $-0.034 * * *$ & $-0.046 * * *$ \\
\hline Hispanic & 0.105 & 0.307 & 0.111 & 0.315 & 0.015 & 0.005 & 0.001 & -0.012 \\
\hline Hispanic, 2000 & 0.074 & 0.262 & 0.081 & 0.273 & $-0.044 * *$ & $-0.048 * *$ & $-0.064 * * *$ & $-0.062 * * *$ \\
\hline Other Non-White & 0.015 & 0.122 & 0.015 & 0.123 & $-0.026 * * *$ & $-0.047 * * *$ & $-0.064 * * *$ & $-0.095 * * *$ \\
\hline Other Non-White, 2000 & 0.013 & 0.113 & 0.013 & 0.114 & $-0.017 * * *$ & -0.011 & 0.007 & $0.021 * * *$ \\
\hline Naturalized Citizen & 0.058 & 0.233 & 0.055 & 0.228 & $0.049 * * *$ & $0.047 * * *$ & $0.022 * * *$ & $0.024 * * *$ \\
\hline Naturalized Citizen, 2000 & 0.040 & 0.196 & 0.038 & 0.192 & $-0.040 * * *$ & $-0.034 * * *$ & $-0.023 * * *$ & $-0.020 * * *$ \\
\hline Non-Citizen & 0.077 & 0.267 & 0.084 & 0.277 & 0.006 & -0.003 & 0.002 & -0.002 \\
\hline Non-Citizen, 2000 & 0.055 & 0.228 & 0.062 & 0.242 & $-0.091 * * *$ & $-0.088 * * *$ & -0.008 & -0.001 \\
\hline Lives in State of Birth & 0.512 & 0.500 & 0.507 & 0.500 & $0.018 * * *$ & $0.021 * * *$ & $0.003 * * *$ & $0.005 * * *$ \\
\hline Lives State of Birth, 2000 & 0.286 & 0.452 & 0.284 & 0.451 & -0.002 & -0.003 & $-0.009 * * *$ & $-0.011 * * *$ \\
\hline Year 2000 & 0.572 & 0.495 & 0.576 & 0.494 & -0.016 & $-0.035 * *$ & $-0.037 * *$ & $-0.025^{*}$ \\
\hline Individual Observations & \multicolumn{2}{|c|}{$3,980,559$} & \multicolumn{2}{|c|}{$3,813,115$} & \multicolumn{2}{|c|}{$3,980,559$} & \multicolumn{2}{|c|}{$3,813,115$} \\
\hline
\end{tabular}

*Significant at 10\%; **Significant at 5\%; ***Significant at $1 \%$. 

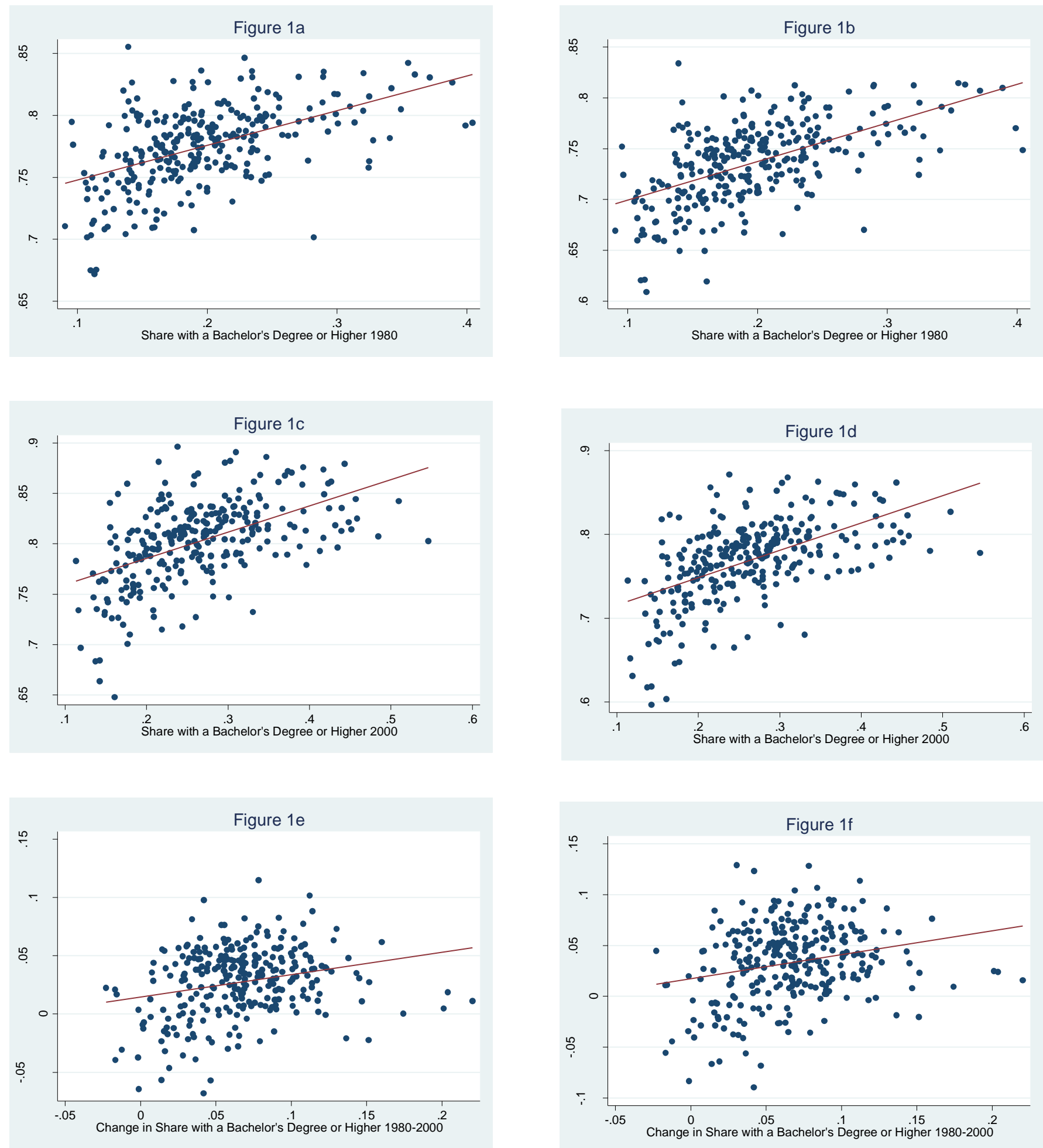